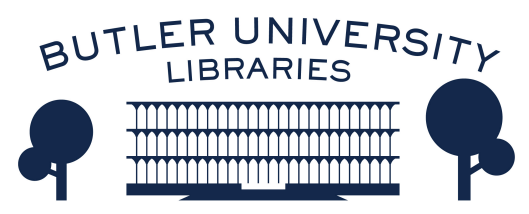

Journal of Hindu-Christian Studies

Volume 27

Article 4

November 2014

\title{
Interiority and Connectivity: A Brief Comparative Study on the Relation of Scripture and Contemplation in Bridal Mysticism and Krishna Bhakti
}

Graham M. Schweig

Christopher Newport University

Follow this and additional works at: https://digitalcommons.butler.edu/jhcs

Part of the History of Religions of Eastern Origins Commons

\section{Recommended Citation}

Schweig, Graham M. (2014) "Interiority and Connectivity: A Brief Comparative Study on the Relation of Scripture and Contemplation in Bridal Mysticism and Krishna Bhakti," Journal of Hindu-Christian Studies: Vol. 27, Article 4.

Available at: https://doi.org/10.7825/2164-6279.1576

The Journal of Hindu-Christian Studies is a publication of the Society for Hindu-Christian Studies. The digital version is made available by Digital Commons @ Butler University. For questions about the Journal or the Society, please contact cbauman@butler.edu. For more information about Digital Commons @ Butler University, please contact digitalscholarship@butler.edu. 


\title{
Interiority and Connectivity: A Brief Comparative Study on the Relation of Scripture and Contemplation in Bridal Mysticism and Krishna Bhakti
}

\author{
Graham M. Schweig \\ Christopher Newport University
}

\section{INTRODUCTION}

Modern psychoanalytic thinkers have claimed that love is the highest virtue (Erikson) or most powerful striving in humans (Fromm). Many in the realm of the sacred make this claim about love as well. In fact, the picturing of God as supreme lover, as the ultimate beloved, has persisted in the religious imagination for many centuries in different parts of the world. Even today the vision of God as lover and beloved is still very much alive. ${ }^{1}$ Theisms that tend to grant little, or preclude entirely, attention to this more intimate dimension of the divine emphasize and focus more on the power, majesty, and sublimity of divinity. But that theistic vision of a religious tradition that celebrates and emphasizes God's nomenclature, personal attributes, and divine acts centered upon and most expressive of the amorous or passionate love either between the soul and divinity or between two divine personages, I choose to identify with the word intimacy, or with such phrases as divine intimacy or theistic intimism. ${ }^{2}$

In this study I bring two disparate traditions together which have painted portraits of divinity as a divine lover and supreme beloved. One tradition is from sixteenth century Europe and the other from sixteenth century India. My focus here is on the function of contemplative experience and vision in relation to the scriptural depictions and descriptions of divine love within both Carmelite Catholicism and Caitanya

Graham M. Schweig is a scholar of comparative religion who focuses on the religions of India and comparative theology. He is a specialist in love mysticism, yoga philosophy, bhakti traditions, and sacred Sanskrit texts. He did his graduate studies at Harvard University and the University of Chicago, receiving his doctorate in Comparative Religion from Harvard. Schweig taught at Duke University, was Visiting Associate Professor of Sanskrit at the University of Virginia, and is a regularly invited lecturer at the Smithsonian Institution. He is currently professor of philosophy and religious studies at Christopher Newport University, Virginia. His book, Dance of Divine Love: The Rāsa Lìlā of Krishna from the Bhāgavata Purāna, was published by Princeton University Press (2005), Bhagavad Gìtā: The Beloved Lord's Secret Love Song, was published by Harper Collins Publishers (2007), and most recently the edited volume, A Living Theology of Krishna Bhakti, by Tamal Krishna Goswami, published by Oxford (2012). Two other books are forthcoming from Columbia University Press: The Bhakti Sūtra: Nārada's Concise Teachings on Divine Love, and Bhagavad Gitā Concordance: Comprehensive Word Reference. 
Vaishnavism through the developed visions in the sixteenth century works of Saint John of the Cross and Krishnadāsa Kaviraja Goswami, respectively. I will argue that both of these poet-theologians develop a deeper, more intimate vision of the divine through an intratextual exercise that involves the combining of specific revelational material from sources beyond their core canonical literature, thus achieving, in the end, a certain kind of intensification of divine intimacy that satisfies each tradition's strivings of the inmost heart in contemplation. Along the way, I attempt to bring these two representative poettheologians into a dialogue of sorts by observing the parallels in their ways of achieving an expanded revelation of divine intimacy.

My focus on the "bridal mysticism" of John of the Cross and the "bhakti mysticism" of Krishnadāsa Kavirāja Gosvāmin first begins with an exploration of their ultimate visions of divine love, most heavily informed by the Song of Solomon in the Hebrew Bible for John and the Rāsa Līlā Pañcādhyāyī of the Bhāgavata Purāṇa for Krishnadāsa. Our two authors refer to, depend upon and quote from these specific respective scriptural sources more than any other. Thus these two specific scriptural sources form, for their respective traditions, not only the foundational sources for divine intimacy, but also the very palettes from which our authors paint their theological portraits of divine intimacy. It is important to recognize some shared moments within these two traditions of divine intimacy as they reveal some parallel dynamics-dynamics that arise from those found in the very nature of love itself.
The scope of this topic is potentially too ambitious, because of the several complex and rich intra- as well as inter-religious themes touched upon here. However, my scope is narrowed by heavily leaning toward a Gadamerian hermeneutical approach that focuses primarily on texts and the specific way of interpreting them by a singularly important theologian of the tradition. ${ }^{3}$ It is not within the scope of this essay to provide historical background of the two theologians from whom and between whom we only wish to observe certain particular dynamics within theistic intimism. What is hopefully achieved here is specifically the raising up of an intra-religious articulation of the theological construction within two traditions of theistic intimism and the attempt to set both these traditions within the comparative inter-religious framework of a dialogue.

\section{Confessions of a comparativist}

Before observing comparative parallels or perhaps even connections between each of the two foundational scriptures that have exhibited divine intimacy within the two historically distinct and different traditions examined, it would be prudent to ask the following question: What is the purpose of a comparative study such as this? What is the motive behind such a study that examines these two theologians who focus on divine intimacy?

In the most general sense, I insist that our purpose here is to know more about what it means to be a human being. As Wilfred Cantwell Smith has written, “. . . in comparative religion man is studying himself." ${ }^{4}$ Moreover, I am interested in what it means when humans act from the heart with faith, when humans grasp something of reality as truth, when 
humans experience the sweetness and fullness of reality that forever beckons us in the overabundance of love that can continuously flow from the core of one's heart to another's, to all life, to all existence.

Even more specifically, here we engage in a comparative theological study to know more of the phenomenon of what it is to love God passionately and intimately. And to know more about this love, we compare in order to illuminate further, to observe interreligious parallels or even correspondences that might reveal a shared theological moment, perhaps a small cloudburst of light that can reveal more of the nature of divine love and theistic intimacy in either but hopefully both traditions. I believe that such a comparative study goes beyond a mere intellectual exercise to some kind of contribution to greater understanding between humans, to a greater sensitivity to others, and to a more elevated state of dialogue.

In pursuit of all this, I would like to confess that I am inspired, motivated, and informed by a specific statement found in the Vedic tradition and a specific statement found in the Catholic tradition for conducting such a comparative study. There is a well-known, much celebrated Hindu adage. It is often engaged as a well-meaning Hindu way of understanding the unity amidst the diverse religious traditions in the world. This adage is often worded in the following way: "Truth is one. Paths are many." Another rendering of this adage goes like this: "Truth is one. Sages call it by many names." And there could easily be variations of either of these very loose renditions. What is important to note here is the essential message most likely intended by these types of popular and slightly misleading renderings: There is something that unifies human beings in their many ways (as in "paths are many") of grasping the one ultimate reality (as in "truth is one").

A precise or faithful translation of the original source of these sayings, originally located in the Vedas, reveals these very intentions in clearer language, which is important for our purposes here:

There is one (ekam) Reality (sat) about which vibrant persons (viprā) in various ways (bahudhā) speak (vadanti). ${ }^{6}$

This Vedic adage clearly presents the one Reality and the vibrant persons who speak about it in diverse ways. Truly the ancient Vedic tradition perhaps presents the earliest vision of a religious pluralism. Moreover, from what is subtly implied in this Vedic passage, we can derive the dynamics or more specifically what I will call the four axes of dialogue. In the briefest number of words, the four axes of revelation in dialogue can be described as follows:

(1) The one Reality (sat) in which everything exists and by which everything is embraced;

(2) The worshipper who is first inspired (vipra) by his or her specific tradition (bahudhā),

(3) The inspired worshipper (vipra) who then speaks (vadanti) as a partner in dialogue to another worshipper,

(4) Together, out from whose dialogical interaction comes an even greater revelation of the one Reality (sat).

These four axes might be diagrammatically illustrated as in Figure 1 below. ${ }^{7}$ 


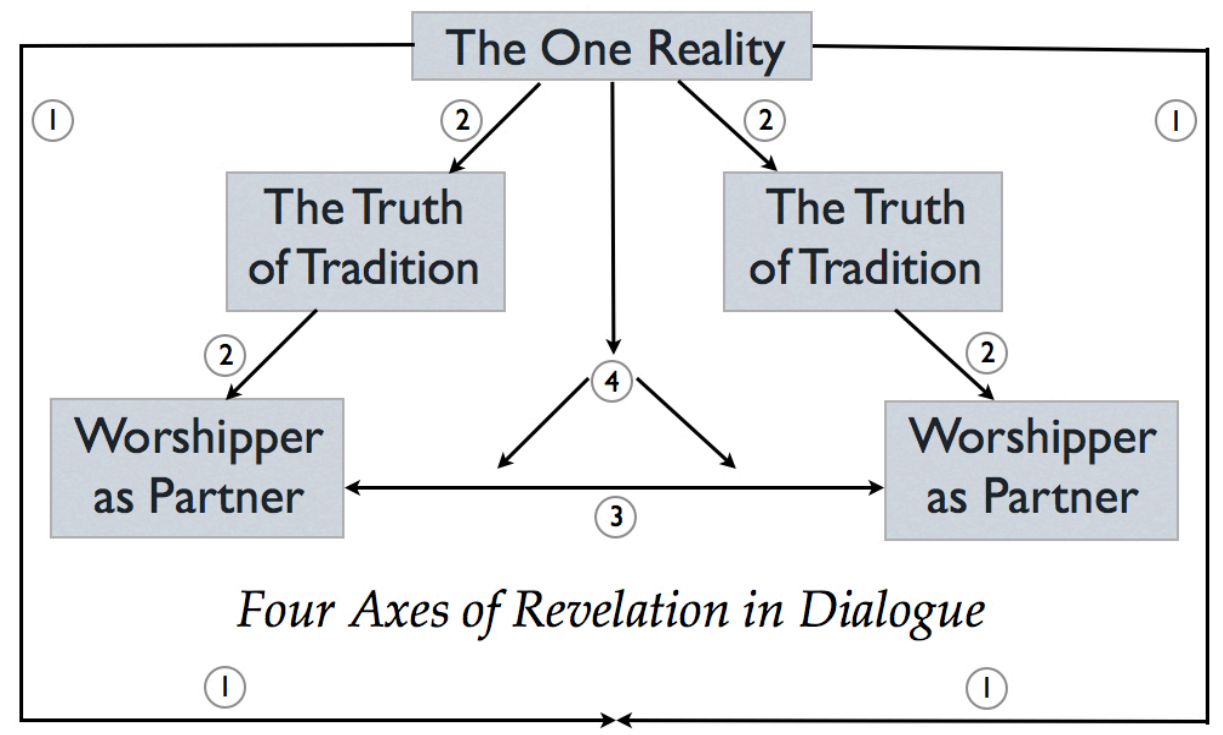

FIGURE 1.

These four axes of revelation in dialogue warrant further explanation.

(1) The first axis, identified as number one of the arrowed lines in Figure 1, conveys the all-embracing "one Reality" in which everything exists, all truths, all dialogues, etc. It is the divine embrace that a partner in dialogue should experience and feel behind everything. It represents the outermost reaches of existence that ultimately supports each and every dialogue and all such partners within dialogue. Each interlocutor feels an absolute humility in such a divine embrace of Reality. Moreover, there is "one reality" in which we all find ourselves, no matter what our faith orientation may be. Everything exists together in this one totality of reality no matter what religious truth we may hold as absolute, whatever we believe or truth claim we may make. Whatever exists is contained within this "one reality" which, in the Sanskrit, is presented as ekam sat. Here dialogue is benefitted by such a starting point and a priori orientation: it assumes that in each interlocutor there is a total openness, humility, and attitude of initial acceptance of any position in whomever it is that is encountered as one's partner in dialogue.

(2) This axis represents the tradition's ultimate vision of divine love, and the grasp of the one Reality. It also represents the interlocutor's depth experience of his or her tradition's truth or vision of the one Reality. Persons who directly experience a connection or a relationship with that one Reality do so through the truth or vision experienced and cultivated in and through a specific tradition. Each practitioner or worshipper is a vipra (literally "shaking"), a "vibrant" or a person "inspired" by tradition. Such deeply inspired persons shake or vibrate in their experience or relationship with what is perceived as "the 
absolute truth," through a specific tradition. This second axis understands that "the truth" or "the absolute truth (satya)" is not to be confused or conflated with the one Reality (sat). Rather, "the truth," pursued as the second revelational axis of dialogue, is the human reaching for reality. It is on this second axis that we can locate these two most powerfully influential sacred love stories, the Biblical Song of Solomon and the Bhāgavata's Rāsa Līlā, as delivering for their respective traditions the ultimate vision of love. By creating a dialogue, as it were, between these two texts, it is my hope that we are, in effect, paving the way for making connections between John and Krishnadāsa, poets and theologians who drew from revelational wellsprings of divine intimacy.

(3) When the worshipper within a tradition becomes a partner in dialogue, the third axis is activated. This partnership occurs when two interlocutors are moved to share what has so deeply moved and inspired each of them by "speaking" about that divine relationship with the one Reality that constitutes their "the absolute truth." From this level of sharing, at this third axis, comes a special bond between hearts, a deep trust between humans, which hardly constitutes any casual exchange. To the contrary, it itself is an act of love, a movement between two persons that itself constitutes a greater and greater intimacy of sharing what is deepest in each of their hearts. It is here that it is most appropriate to engage a question that St. Augustine asks at the start of one of his passages in his work, Confessions, to which he responds with the most beautiful prose: "What do I love when I love my God?" 8 The very question presupposes a certain grasp of reality, a deeper sense of one's own more intimate connection and vision of the divine, and a certain anticipation of a dialogue and even greater revelation of divine love. Here, my attempt is to conduct a dialogue between the two thinkers in the spirit of this Augustinian interrogative.

(4) The fullness of the one reality is such that there is no end to the experiences that such inspired persons can have of it, and thus the "various ways" of speaking about their relationships with the one Reality are endless. What will invariably emerge between partners in such a dialogue is the special kind of revelation of the one Reality that cannot be found anywhere else. The Rig Vedic passage thus reveals the unique form of revelation of the one Reality that will invariably form the very basis of authentic dialogue and the very ground on which a genuine religious pluralism is built, and further, expresses an interfaith ethos that forms a foundation from which ultimately a greater revelation of the one Reality will come.

\section{Two scriptural portraits of divine intimacy}

In both traditions, we can observe a theopoetics of divine love. The song of Solomon (SS) functions as the foundational scriptural vision of divine love for Carmelite Catholicism, and the Rāsa Lìlā (RL) similarly functions for Caitanya Vaishnavism. Yet there are more nuanced similarities and differences, no matter how blatant or subtle they may be, that are worth reviewing here, but only in pursuit of creating an authentic dialogue between both traditions.

While both passages can easily be classified as "sacred love stories," there are striking differences between them. Of course, the Semitic background and ethos of the SS 
certainly contrasts with the RL, which is saturated by its Indic background and ethos. And while both textual passages are found within the context of scripture and certainly deemed canonical, it is important to point out that the SS is found outside the core canon of the New Testament, as it is situated in the Hebrew Bible or "Old Testament," whereas the $\mathrm{RL}$ is found at the very pinnacle of the core canonical text, the Bhāgavata Purāna. The SS is also well known to be discontinuous with, or more autonomous from its surrounding texts within the Hebrew Bible. It stands on its own, due to its radically different subject matter than what is found in the Bible, and it contains nothing that is connected narratively or even theologically or historically to the rest of the Bible. It gains its attention, its appreciation and its sacred value by the very fact that it exists in the Bible. The RL, on the other hand, is integrated into and is a constituent part of the character and narrative flow of the whole of the Bhāgavata text.

There are further literary considerations. The SS is a patchwork quilt of raw poetic fragments, whereas the RL is a highly redacted, tightly put together drama and poem. The SS is an overtly erotic love story with no references to the divine, while the RL is a love story having erotic overtones with specific references to the divine. The former is apparently a romance of this world, while the latter appears to be a romance of a divine world. The former is described with impressionistic metaphor, and the latter with a certain amount of naturalism and realism. The SS has a singular heroine with a hint of the plurality of heroines, whereas the RL has a singular group of heroines with singular voices often representing the group. Although in both works, there is a singular male hero, and there is a preponderance of the female voice in both (in fact, there is no other text within the Bible where the feminine voice is so prominent as we find in the SS, and similarly, it is also the case with the RL), it is the heroine who speaks on the nature of love, whereas it is the hero of the RL who speaks on the nature of love. In the SS, one finds eight chapter divisions with 117 numbered lines, while in the RL, one finds five neatly arranged continuous chapters divisions with 173 quatrain verses. The SS involves two unmarried lovers within a natural paradisal worldly setting, whereas the RL involves many adulterous heroines with an unmarried hero in a paradisal divine world. The presence of nature and its pastoral setting, with nuanced descriptions of the foliage and fruits in this paradisal setting is powerful in both passages, but yet plays different roles within the dramas of each.

\section{The Song of Songs and the Rāsa Lìlā in dialogue}

The strong differences among these two great sacred texts are a testament to their uniquenesses, their self-contained worlds, their distinct portraits of divine love that are complete unto themselves as autonomous expressions that need nothing from anywhere else-portraits that indeed represent an exclusive knowledge and vision of the divine. At the same time, paradoxically, each text receives an intrareligious, intracanonical expansion, embellishment, and intensification of its portrait of love. This will be reviewed in the final section of this article. But what is important here is that while each text receives the utmost respect for their complete, perfect, and autonomous expression of divine love, it also receives, amazingly, even despite its 
ultimate status within the tradition, a furthering of its vision, a continuation, an expansion, an even deeper development of its depths of expression.

Here, we are stretching this continuation, expansion and development beyond traditional boundaries into an interreligious conversation that focuses on key theopoetic themes of divine intimacy. Here, we dare to share within the dynamic of a dialogue, a dynamic that assigns two shifting roles for each interlocutor: (1) reception, and (2) contribution, which results in lifting both partners into a heightened sense of connection, a certain subtle state of an interreligious communion, even revelation. My intention here, is that the back-and-forth of dialogue, the interplay between reception and contribution is perceived by the reader of this article when encountering the sixteen themes within love, provided below, in which select verses or lines from the SS and the RL participate but, of course, in their own particular ways.

Here it is my attempt to bring both these great texts into dialogue. All quoted passages for each work are taken from two specific translations of each work. For the biblical Song of Solomon, I am using The Song of Songs, by Ariel Bloch and Chana Bloch, ${ }^{9}$ and for the Bhāgavata's five chapters of the Rāsa Lìlā, I use my own translation from my book, Dance of Divine Love. ${ }^{10}$ Below I present sixteen themes related to love that can be observed as present in some form in the poetry of both works. Each work speaks of the female lover, the heroine (or group of heroines), who symbolizes or represents the human soul or a divine personage, either in the singular or the plural, identified here in my headings as "The Lover." And each also speaks of the male lover, the hero who symbolizes or represents a divine personage or divinity himself, identified in the themes as "The Beloved." heading (in bold type), I first present the poetic lines or verses from the SS that engage this theme, and then I present poetic lines or verses from the RL that also engage this theme.

It is important to underscore that this dialogue is really the back-and-forth between the central element within two of the second axes of dialogue, namely "the truth of tradition," as represented by the two most exquisite scriptural expressions of divine intimacy according to certain Jewish-Christian and Hindu-Vaishnava traditions. Despite the differences between the two works, in voicefor example, one text may demonstrate participation in a theme with a first person voice and the other may do so with a third person narrative voice-or in tone, or in setting, etc., it is my hope that the juxtaposition of these passages, subsumed by these various themes on love, will give way to a dialogue that must take place within us, the reader, and itself is fulfilled and yet is further advanced by the reader's considerations and reflections.

\section{The Beloved's call to love}

Oh come with me, my bride, come down with me from Lebanon. Look down from the peak of Amana, look down from Senir and Hermon, from the mountains of the leopards, the lions' dens. 
Seeing the forest colored

by the moon's gentle rays,

He began to make sweet music, melting the hearts of fair maidens with beautiful eyes.

RL 1.3

The Beloved as best among men

And my beloved among the young men ...

SS 2.3

O jewel among men...

RL 1.38

The Lover as best among women

Loveliest of women...

SS 1.8

The shepherd

Like a lily in a field

of thistles,

such is my love

among the young women.

SS 2.2

Threescore are the queens, fourscore the king's women, and maidens, maidens without number.

One alone is my dove, my perfect, my only one, love of her mother, light of her mother's eyes.

Every maiden calls her happy, queens praise her, and all the king's women:

SS $6.8-9$

Thus those who received honor from the Beloved Lord,
Krishna, the great Soul, Thought themselves the best among all women in the worldthey then became filled with pride.

RL 1.47

\section{All the maidens love the Beloved}

All the young women want you.

SS 1.3

Everyone of them wants you.

SS 1.4

O dear one, what woman

in the three worlds

would not abandon

her noble character,

After being overcome

by the sweet melodious

music of your flute?

Seeing your beauty, the most magnificent

in all the three worlds,

The animals, trees,

birds and cows are elated

with bodily ripplings of bliss.

RL 1.40

\section{Love's awakening}

Chorus of Maidens

"Who is that rising like the morning star, clear as the moon,

bright as the blazing sun, daunting as the stars in their courses!"

The shepherd

Then I went down to the walnut grove to see the new green by the brook, to see if the vine had budded, if the pomegranate trees were in flower. 
And oh! before I was aware, she sat me in the most lavish of chariots.

SS 6.10-12

Even the Beloved Lord, seeing those nights in autumn filled with

blooming jasmine flowers,

Turned his mind toward

love's delights, fully taking refuge in

Yogamāyā's creative powers.

RL 1.1

\section{Abandoning everything and running off for love}

Take me by the hand, let us run together!

SS 1.4

Before day breathes, before the shadows of night are gone,

run away, my love!

Be like a gazelle, a wild stag

on the jagged mountains.

SS 2.17

The Maiden

Hurry, my love! Run away, my gazelle, my wild stag

on the hills of cinnamon.

Upon hearing that sweet music, their passion for him swelling, The young women of Vraja whose minds were captured by Krishna, Unaware of one another, ran off toward the place Where their beloved was waiting,

SS 8.14 with their earrings swinging wildly.

RL 1.4

Some were massaging

their bodies with oils

or cleansing themselves;

others applying

ointment to their eyes.

Their garments

and ornaments

in utter disarray,

they hastened

to be with Krishna.

Their husbands, fathers, brothers-

all relatives endeavored

to detain them.

Since their hearts

had been stolen by Govinda, they who were entranced

did not turn back.

RL 1.7-8

\section{The Lover seeks the Beloved}

At night in my bed I longed

for my only love.

I sought him, but did not find him.

I must rise and go about the city,

the narrow streets and squares, till I find

my only love.

I sought him everywhere

but I could not find him.

Then the watchmen found me as they went about the city. "Have you seen him? Have you seen the one I love?"

I had just passed them when I found 
my only love.

I held him, I would not let him go

until I brought him to my mother's house,

into my mother's room.

SS 3.1-4

I opened to my love

but he had slipped away.

How I wanted him when he spoke!

I sought him everywhere

but could not find him.

I called his name

but he did not answer.

SS 5.6

By his movements,

affectionate smiles, passionate glances,

His attractive speaking

and the passion of

his playfulness,

Their hearts were captivated;

those crazed women

began to imitate various

Actions of the Lord of Ramā,

losing themselves,

fully absorbed in him.

RL 2.2

Singing out loud about him

like deranged persons,

Together they searched

from forest to forest.

They inquired from trees,

the lords of the forest,

about the supreme Person

Who is present internally and

externally for all living beings,

as heavenly air pervades all beings,

within and without.

RL 2.4

\section{The Beloved seeks the Lover}

And he calls to me:

(The shepherd)

Hurry, my love, my friend,

and come away!

Look, winter is over,

the rains are done,

wildflowers spring up in the fields.

Now is the time of the nightingale.

In every meadow you hear

the song of the turtledove.

SS $2.10-12$

Then I went down to the walnut grove to see the new green by the brook, to see if the vine had budded, if the pomegranate trees were in flower.

SS 6.11

Dear ladies, indeed, for my sake alone

You have abandoned the world, the Vedas and even your relatives, out of love for me.

It was out of love for you that I became invisible, though you were never removed from my sight.

Therefore, you should not be discontented with me$O$ dearest ones,

I am your beloved!

RL 4.21

\section{The Lover's passion for the Beloved}

Kiss me, make me drunk with your kisses!

Your sweet loving

is better than wine. 
You are fragrant,

you are myrrh and aloes.

...

Take me by the hand, let us run together!

My lover, my king,

has brought me into his chambers.

We will laugh, you and I, and count

each kiss,

better than wine.

SS $1.2-4$

That pleases my lover, rousing him

even from sleep.

...

Come, my beloved,

let us go out into the fields

and lie all night among the flowering henna.

Let us go early to the vineyards

to see if the vine has budded,

if the blossoms have opened

and the pomegranate is in flower.

There I will give you my love.

The air is filled with the scent of mandrakes and at our doors

rare fruit of every kind, my love,

I have stored away for you. SS 7.10, 12-14

You have ravished my heart,

my sister, my bride,

ravished me with one glance of your eyes,

one link of your necklace.

And oh, your sweet loving,

my sister, my bride.

The wine of your kisses, the spice

of your fragrant oils.

Your lips are honey, honey and milk are under your tongue, your clothes hold the scent of Lebanon.

SS $4.9-11$

O dear one,

with the flood of nectar

coming from your lips,

Extinguish the fire

burning within our hearts

born of your sweet music,

your glances and laughter.

For if you don't,

we shall place

our bodies in the fire

born of separation from you.

Then, $\mathrm{O}$ friend,

by means of meditation

we shall go to the abode of your feet.

RL 1.35

Acyuta, whose actions are exalted, whose jasmine-like teeth

shone forth from his eloquent smile, joined together with all of them, Whose faces were blossoming with loving glances;

He was glowing like the full moon surrounded by stars.

RL 1.43

Embracing them with wandering arms; playfully touching their hands with the tips of his fingernails

Which then fell upon their breasts, belts, thighs, and hair;

Conversing coyly

with glances and laughter,

He joyfully awakened the god of love 
in those beautiful young women from Vraja.

RL 1.46

The Lover craves kisses of the Beloved Kiss me, make me drunk with your kisses!

SS 1.2

His mouth is sweet wine, he is all delight.

SS 5.6

The nectar that

strengthens our love and vanquishes our grief;

The nectar that is abundantly kissed by the flute you play, Making everyone forget all other attachments;

o hero, please bestow upon us this nectar of your lips!

RL 3.14

\section{Oppositions to love experienced by the Lover}

Chorus of Shepherds

We have a little sister

and she has no breasts.

What shall we do for our sister

when suitors besiege her?

If she is a wall, we will build a silver turret upon her.

If she is a door, we will bolt her with beams of cedarwood.

SS 8.8-9

Their husbands, fathers, brothers- all relatives endeavored to detain them.

Since their hearts had been stolen by Govinda, they who were entranced did not turn back.

Some Gopīs, unable to leave, had gone inside their homes.

With eyes closed, fully absorbed in love, they meditated upon Krishna.

RL 1.8-9

\section{The Beloved's disappearance}

I opened to my love

but he had slipped away.

How I wanted him when he spoke!

I sought him everywhere

but could not find him.

I called his name

but he did not answer.

Keśava could see how they had become intoxicated with their good fortune;

Bestowing upon them his grace, in order to quell their pride, suddenly, right before them, he disappeared.

Thus addressed by his beloved, he replied, "Please climb on my shoulder." Then Krishna suddenly disappeared; the young woman was devastated.

RL 2.38 


\section{The Lover's longing in love}

I opened to my love

but he had slipped away.

How I wanted him when he spoke!

I sought him everywhere

but could not find him.

I called his name

but he did not answer.

SS 5.6
Why do you gaze at the Shulamite

as she whirls

down the rows of dancers?

The Shepherd

How graceful your steps in those sandals, O nobleman's daughter.

The gold of your thigh

shaped by a master craftsman.

SS 7.1-2

While dancing, they sang out loud, and the throats of those so delighted by love became reddened.

They were overjoyed by the touch of Krishna,

RL 2.39

Their minds were

filled with thoughts of him;

they spoke about him constantly;

their movements

were no longer their own

for they were fully absorbed in him.

While praising

his qualities in song

they forgot their homes;

indeed, they even forgot themselves.

RL 2.43

\section{The Lover's dance of love}

Chorus of Maidens

Again, O Shulamite, dance again, that we may watch you dancing! and the whole universe

became filled

with their song.

RL 5.9

One of them, together with Mukunda, sang out in pure embellished tones, freely improvising on a melody.

Pleased by her performance he honored her, saying "Well done!" "Well done!"

Another one sang out that melody in a stylized rhythmic pattern, and he offered her much praise.

Another, weary from the Rāsa dance, stood beside the one who carried a baton;

Placing her arm around his shoulder, 
her jasmine flowers

and bracelets slackened.

RL 5.10-11

The nature of love

Bind me as a seal upon your heart, for love is as fierce as death, its jealousy bitter as the grave. Even its sparks are a raging fire, a devouring flame.

Great seas cannot extinguish love, no river can sweep it away.

If a man tried to buy love with all the wealth of his house, he would be despised.

SS 8.6-7

I am unable to reciprocate your faultless love for me, your own purity,

And all that you have sacrificed for me, even over the lifetime of a great divinity. Severing strong ties to your homes so difficult to overcome, you have lovingly worshiped me.

May your reward be your own purity.

RL 4.22

\section{The purity of love}

The Shepherd

You are beautiful, my love, as Tirzah, majestic as Jerusalem,

daunting

as the stars in their courses.
Your eyes! Turn them away

for they dazzle me.

Your hair is like a flock of goats

bounding down Mount Gilead.

Your teeth white ewes,

all alike,

that come up fresh from the pond.

The curve of your cheek

a pomegranate

in your thicket of hair.

SS 6.4-7

I am unable to reciprocate

your faultless love for me, your own purity,

And all that you have sacrificed for me, even over the lifetime of a great divinity.

Severing strong ties to your homes so difficult to overcome, you have lovingly worshiped me.

May your reward be your own purity.

RL 4.22

\section{Two unique poet-theologians of divine intimacy}

In the most general terms, the intimacy between the soul and God, between the Lover and the Beloved, and the love between them, are described by both John and Krishnadāsa in great depth in their respective works, as each relies on what they perceive as the most important scriptural expressions of divine love and intimacy. They both draw from a variety of core and peripheral canonical sources, but mostly from the SS for John and the RL for 
Krishnadāsa, the ultimate scriptural statements within their canonical core texts. Each obviously, however, provides different nomenclature, identifications, and descriptions with different shades and degrees of vividness, as well as different spiritual environments and worlds. When experiencing the SS and RL in dialogue with one another, these differences have easily come more into focus. So it is the case with each of our poet-theologians.

John and Krishnadāsa present an altogether different "theography" of divine love. When John speaks of amor de Dios ("love of God"), or amor divino ("divine love") and when Krishnadāsa speaks of prema-bhakti ("pure love of God"), or śuddha-bhakti ("pure devotion"), they are describing different portraits of union and divine intimacy. John presents the female lover in the SS as the soul as the esposa or "bride," and John calls the male lover in the SS a bridegroom, even though they are not referred to as such in the SS itself. ${ }^{12}$ The bride attains union with God, who is the esposo or the "bridegroom," identified as Christ, in the matrimonio espiritual, or "spiritual marriage." The imagery of the bride and Bridegroom is impressionistic, that is, selectively detailed imagery with much left to the imagination. Krishnadāsa presents the soul ultimately as a gopi (literally, a "cowherd maiden," or connotatively a paramour-consort). The gopi attains union with God, who is the supremely beautiful, playful, and delightful bluish cowherd boy, or gopa, identified as Krishna, in his lìlā, or amorous acts, known more generally as mādhurya-līlā, or more specifically as śrngārarasa. The imagery of Krishna with the gopis is naturalistic, elaborately detailed with picturesque vividness.
Each presents similar metaphysical relationships for divine intimacy, that is, any relationship with God in which the soul and God are eternally distinct entities who are united with one another by a love that resembles the dearest and closest of loving feelings and exchanges between humans, namely, the conjugal or romantic or even erotic, lover-beloved relationship. Both traditions join together human love with divine love, in imagery and in a theological drama. Each asserts that the love in divine intimacy is not to be construed as the love of this world, but a love that is radically different than the love of this world; a love that constitutes an absolute level of purity of consciousness while so-called "erotic" imagery is employed to represent the intensity of this pure love. ${ }^{13}$ Each describes a spiritual energy that belongs to a divine realm in which both God and the soul lose themselves in love. The soul and God elope in a mystical realm, as it were, that is not of this world and it is not of heaven either. The soul leaves the pleasures and miseries of this world to be with an intimate deity who is no longer functioning as the Creator or the generator of the cosmos. They meet in a realm that is not exactly their own, be it the "bridal chamber," or the "groves of Vrindaban." This domain is a world of love, a realm of spiritual energy that possesses a life all its own, a spiritual world away from the everyday world and the divine "burdens" of cosmic management, a world that is perfectly suitable for the intimate exchanges of love between God and his devotee.

The world of divine intimacy that both authors establish supports an image of this special realm for both the soul and God, because, as they both show, supreme love itself has a life of its own, even beyond God and the 
soul. In John it is called the espiritu santos ("holy spirit"), and in Krishnadāsa it is called the yoga māy $\bar{a}$ ("mystical energy of union"). This "spirit" or "energy" comes from God, and yet it is something on which even he, as well as souls, becomes dependent, and thus it remains separate from him.

\section{Intensification of divine intimacy in John}

From the foregoing we were able to observe the ways in which the visions of divine intimacy as presented in the foundational sacred texts for the Carmelite and Vaishnava traditions participated in the many articulated themes and dynamics within love. Here we will observe the ways that both John and Krishnadāsa participate in a process of intensifying their visions of divine intimacy. Effectively, they each, in their own ways, allow for a further unfolding of a revelation of divine intimacy. This process consists of a blending, even a fusing, of what is perceived as the key elements from the most important expressions of divine intimacy within both their peripheral and core canonical works. For our poettheologians, the interiority of contemplation is deepened by making certain connections within and between specific dimensions of intimacy among scriptural writings. Consequently, these connections themselves constitute a greater revelation of divine intimacy, informing and deepening contemplation.

From John's description of what contemplation entails through a colorful metaphor, we can surmise the very contemplative process through which he himself goes. Contemplation for John has the traits of the solitary bird, traits that John states "must be possessed by the contemplative soul":
The traits of the solitary bird are five: first, it seeks the highest place; second, it withstands no company; third, it hold its beak in the air; fourth, it has no definite color; fifth, it sings sweetly." 14

He then elaborates on all five:

These traits must be possessed by the contemplative soul. It must rise above passing things, paying no more heed to them than if they did not exist. It must likewise be so fond of silence and solitude that it does not tolerate the company of another creature. It must hold its beak in the air of the Holy Spirit, responding to his inspirations, that by so doing it may become worthy of his company. It must have no definite color, desiring to do nothing definite other than the will of God. It must sing sweetly in the contemplation and love of its Bridegroom. ${ }^{15}$

The actions John describes of a solitary bird constitute the actions that naturally occur in love: a person in love naturally rises above everything, is naturally focusing on the beloved away from everything else, is naturally inspired and drawing from the love and beauty of the beloved, and is naturally singing sweetly about the one who is loved. But here the beloved, or object of love, is described as "the Bridegroom." Interestingly, and important for our discussion here, is the obvious-there is no mention of God, or for that matter, Jesus, as a Bridegroom in the New Testament.

John drew extensively in his extensive writings from a plethora of scriptural texts within the whole biblical canon. Indeed, the greatest quantity of references and quotations 
come from the book of Psalms, the Song of Solomon, and then the Gospels of Matthew, Luke, and John, Isaiah, and so on. However, it is clear that John drew his greatest inspiration from two canonical sources, one peripheral and one central to the Christian canon: the Biblical Song of Solomon and the New Testament's Passion of Christ, respectively. It is precisely these two passages, these two sources that are fused to paint a more intimate portrait of the divine that depicts Christ as the divine bridegroom, and the deeply contemplative soul as the bride.

John's contemplation brings together his vision of divine intimacy in his erotically charged poetry. His vision of divine love depicts an intensity of longing and belonging between the bride and Christ, the bridegroom, further intensified by motifs of suffering imagined in the passion. John's contemplation draws from the visions provided by two scriptural texts, primarily, and then expresses the intensity and depth of feeling through his own poetry on divine love. John writes poetry that is imitative of the SS and engages the motifs of the suffering Jesus. In the following examples, note the various expressions that blend love and suffering. The first two opening verses of his poetry in The Spiritual Canticle are especially demonstrative of this blend (bolded print mine), in which the first person voice of the female lover, or the Bride, is speaking:

1. Where have you hidden, Beloved, and left me moaning?

You fled like the stag

after wounding me;

I went out calling you, but you were gone.

2. Shepherds, you who go up through the sheepfolds to the hill,

if by chance you see

him I love most, tell him I am sick, I suffer, and I die.

Certainly it is possible to find some of these themes of suffering in the biblical song of Solomon, but not with nearly the level of intensity as we can observe here in John's words. ${ }^{16}$

Other passages from John's Canticle similarly contain this blend of suffering and love: "All who are free / tell me a thousand graceful things of you; / all wound me more and leave me dying ..." and "Why, since you wounded / this heart, don't you heal it?"18 And finally, in the voice of the beloved Bridegroom, we find words in the third person declaring that he too experiences the wound of love: “. . . he alone, who also bears in solitude the wound of love." ${ }^{19}$ Additionally, in the poetry of John's work, The Living Flame of Love, we find in the words of its opening stanza a very dramatic expression of this blend: "O living flame of love / that tenderly wounds my soul / in its deepest center! ..." And in the work's second stanza, again, we observe not only the positive value of suffering or death, but its salvific function as well as its role in intensifying love:

2. O sweet cautery,

0 delightful wound!

o gentle hand! o delicate touch

that tastes of eternal life

And pays every debt!

In killing you changed death to life.

John devotes much of his writing to explain these expressions of being wounded, of dying, of death, of killing, or moaning, etc., in love, 
particularly in the exegetical commentaries he provides to elaborate on his own poetry. We find especially such explanations in the comments to the stanzas presenting these phrases. For example, in the following John explains the elements of wounding, slaying, sickness, and blends these with the elements of healing, living, health, etc.:

3. Her [the soul's] complaint is not that he wounded her-for the more a loving soul is wounded the more its love is repaid-but that in sorely wounding her heart, he did not heal her by slaying her completely. The wounds of love are so sweet and delightful that if they do not cause death they cannot satisfy. Yet they are so delightful that she would want them to wound her sorely until they slay her completely. Consequently she says: "Why, since you wounded this heart, don't you heal it?" This is equivalent to saying: Why, since you wounded this heart until it has become sorely wounded, do you not heal it by wholly slaying it with love? Since you cause the sore wound in the sickness of love, may you cause health in the death of love. As a result the heart, wounded with the sorrow of your absence, will be healed with the delight and glory of your sweet presence. ${ }^{20}$

From the foregoing, it is clear that John blends the lover-beloved theme of the Song of Solomon with themes arising from the passion, death, and resurrection of Jesus. Deep contemplation on the one intensifies and brings out the elements of the other. The agony of God's absence, its sickness, its passion, its ability to mortally wound the heart of the soul, or bride of Christ, becomes itself the source of healing, eternal life, a source of "delight and glory," a resurrection, as it were, of a reunion between the bride and bridegroom.

Perhaps one of the most dramatic instances in which we can observe a blending of the seemingly incompatible themes of the crucifixion and bridal mysticism is found in the ink drawing of the crucifixion that John executed after coming out of a deep contemplative trance. The composition stands out in the history of crucifixion art: normally, almost invariably, crucifixion depictions in art place the viewer in front of the crucified Jesus, or from an angle on ground level, more or less looking up at Jesus. Here, however, John places the viewer at a three-quarter aerial view above looking down at Jesus, who is darkened by shadow as his body strains forward while his bloody arms and hands with stakes through them are stretched backward to the cross, with the source of light coming from behind it. ${ }^{21}$ The important point to be made here is how this image powerfully presents this fusion of bridal mysticism with the crucifixion event, beautifully articulated in a poetic passage written by John, in which Jesus speaks to God, the Father, and explains that he will die for his bride and deliver her unto him:

“... I will go and tell the world, spreading the word of your beauty and sweetness and of your sovereignty. I will go seek my bride and take upon myself her weariness and labors in which she suffers so; and that she may have life, I will die for her, and lifting her out of that deep, 
I will restore her to you." ${ }^{22}$

Interestingly, John warns his followers against objects or images for meditation. Despite this, he created his famous drawing of the crucifixion which was precipitated by his own deep contemplation. The small pen drawing of the crucifixion that John created following his experience of a deep trance illustrates how he blended the two unlikely themes of the passion and death event with the relationship dynamics within bridal mysticism. Here we have observed the intertextual coalescence of significant themes and key elements from within canonical boundaries. This coalescence gives rise to a newer more intensified vision of divine intimacy, a deeper contemplation, a revelation of intertextual connections that elevates a community's focus.

\section{Intensification of divine intimacy in Krishnadāsa}

In the Vaishnava bhakti tradition, we find, similarly, this intertextual coalescence of significant themes of divine intimacy from peripheral scriptural sources brought together with key elements from core canonical passages, thus intensifying the vision of the intimate dimensions of the divinity for the tradition. The five chapters of the RL are unquestionably the highest vision and ultimate divine event for divinity as presented by the most cherished sacred text for the Chaitanya school of Vaishnavism, the Bhāgavata Purāṇa. I have argued elsewhere that among its 335 chapters, and among its some 14,000 verses, and through its many literary and theological indicators, that the text itself considers the RL as its culminating expression. ${ }^{23}$ Within the thirteen scenes of the five RL chapters themselves, the ultimate event occurs when Krishna duplicates himself multiple times to dance with each and every cowherd maiden, or Vraja Gopikā, in the great circle they all formed around Krishna, who was at the center.

In the RL chapters, none of the Vraja Gopikās are ever named, though there are instances during the RL when individual Gopis are speaking. However, the one Gopi with whom Krishna runs off from all the others stands out. This unnamed Gopi appears to be favored by Krishna, but as the story goes she too is abandoned by him. In the end it is the scene of the great circle dance that takes place among the whole group of the Vraja Gopikās with Krishna that constitutes the RL's culminating scene. Undoubtedly, this is the highest vision on which bhaktas in the Chaitanya Vaishnava tradition endlessly contemplate. Furthermore, the great circle dance has been depicted in drama, poetry, and painting many thousands of times throughout the centuries, one of the most popular religious motifs in all of South Asia. As the crucifixion is the ultimate vision for many Christian traditions, so the great circle dance, the rāsamandala, is certainly for Chaitanya Vaishnavism and the majority of Hindu traditions.

Krishnadāsa is undoubtedly one of the most important theologians of the Chaitanya school because of his most celebrated biography of Chaitanya, known as Caitanya Caritāmrta (CC). After all, it was Chaitanya (1486-1533 CE) himself who set the example of perfect devotion to Krishna, who also established the primacy of five sacred texts for practicing Krishna bhakti. Among these five, it is the $12^{\text {th }}$ Century work of Gitagovinda written by the poet Jayadeva Gosvamin that most powerfully establishes the name and identity of Krishna's 
supremely beloved Vraja Gopikā, Rādhā, and her relationship with Krishna. Early in his work, Jayadeva depicts Rādhā as jealous of the others in the Rāsa event, and thus we find her words expressing Rādhā's jealousy in a refrain:

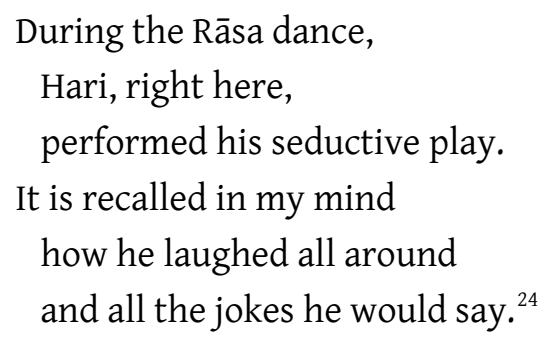

She is understood by the tradition to be Krishna's singularly greatest and most desirable cowherd maiden by Krishna. Furthermore, Jayadeva establishes in his twelve-chapter poem that it is Rādhā with whom Krishna runs off in the Bhāgavata's RL story. Krishnadāsa elaborates on this rendezvous:

Because he was inhibited by the crowds of Gopis, he went off with Rādhā.

Due to the presence of all the others, the intensity of their love did not develop.

If he directly gives up all the other Gopis for the sake of Rādhā,

Then we can surmise the intense passion that Krishna has for Rādhā.

Leaving the circle of the Rāsa dance with all of the groups of Gopis,

Wandering about the forest desiring Rādhā, he became saddened.

Furthermore, the Enemy of Kamsa (Krishna) feeling bound to the essence of pleasure, And having taken Rādhā into his heart, abandoned the beautiful women of Vraja.

Then he, having searched everywhere for Rādhikā,

whose heart was afflicted by the arrow of the god of love,

And feeling bad about his behavior, Mādhava roamed about

the groves along the bank of the river Kalindī. ${ }^{25}$

And most remarkable, Rādhā has taken on such a powerful presence in the tradition's vision of divine intimacy that practitioners cannot even look at the great circle dance event of the RL without being absolutely insistent that Rādhā appears in the middle of the circle of Vraja Gopikās even though there is no mention of any Gopi at the center with Krishna in the original text of the Bhāgavata's RL:

While in the association of hundreds and thousands of Gopīs in the Rāsa dance, He remained in the middle of them in one form by the side of Rādhā. ${ }^{26}$

The Rāsa Lìlā is the full essence of Krishna's desire.

Rādhā is the binding link in his desire for the Rāsa Lìlā. ${ }^{27}$

Without her, the Rāsa Lìlā does not radiate in his heart. Leaving the circle of the Rāsa, he went to search for Rādhā. ${ }^{28}$

The group of Gopis were bound together dancing in the circle [of the Rāsa] 
And in the middle, the son of Nanda danced together with Rādhā. ${ }^{29}$

For bhaktas, it is impossible to contemplate the rāsa-mandala without her appearance with Krishna at the very center of the great RL circle dance. And moreover, most Vaishnava temples conduct worship around the three dimensional sacred images of Rādhā and Krishna. In fact, for the Chaitanya school, the rāsa-mandala is seen as identical to the persons of Rādhā and Krishna, the essential manifestation of the rāsamandala itself. Thus it is the fusion of the Bhāgavata's RL chapters with the Gitagovinda's elaborate treatise on Rādhā's intimate interactions with Krishna.

Krishnadāsa drew from a plethora of scriptural texts within the Vaishnava canon. The greatest quantity of quoted texts comes from the Bhāgavata Purāna, especially the tenth book, and especially the Vraja Lìlās and the RL. Following this, Jayadeva's Gitagovinda and then much later, the poetic works of Rūpa Goswami (16th Century) following Jayadeva's work, highlight the powerful presence of Rādhā in the Krishna's heart. Krishnadāsa brings together the ancient Bhāgavata Purāna's RL with the Rādhā of devotional poetry of the $12^{\text {th }}$ and $16^{\text {th }} \quad$ Centuries. Krishnadāsa's contemplation draws from the visions provided by two scriptural texts, primarily, and communicates the intensity and boundlessness of divine love with an exlusive focus on Krishna's love for Rādhā: Krishnadāsa writes poetry and engages verse that is imitative of the RL and which places Rādhā at the very center of Krishna's divine love.

The Gitagovinda (GG), it could be argued, is a kind of esoteric continuation of the Bhāgavata RL. Additionally, it certainly could be said that the work also functions as a work that eisegetically fills in some of the gaps or what could be perceived as missing information in the RL narrative. Such gaps the tradition found too irresistable to leave alone without any further imaginative elaboration, and Jayadeva, whose inspiration for his work was undoubtedly grounded in the Bhāgavata's RL. A brief comparative analysis of the very important "seed" (bija) verses of the RL and GG is revealing, as the GG's verse not only reflects the four essential elements found in the RL's, but clearly the GG's powerfully conveys its expanded vision of the union of Rādhā and Krishna:

Even the Beloved Lord, seeing those nights in autumn filled with blooming jasmine flowers,

Turned his mind toward love's delights, fully taking refuge in Yogamāyā's creative powers. ${ }^{30}$

"Clouds cover the sky; tamāla trees darken the forest floor.

Tonight he is fearful; Now, O Rādhā, you must lead him to the forest dwelling!" Thus being obedient to joy, they move quickly along a path, toward a tree deep within a grove.

Both Rādhā and Mādhava are conquered there, on the banks of the river Yamunā, 
by the secret ways their divine love plays. $^{31}$

We can observe continuity between the two verses, and also a greater amount of creativity in the verse of the GG, for the GG verse paints a more complete, a more elaborate portrait of divine intimacy. Continuity is found in the presence of four primary elements in both verses:

(1) The hero of the story-RL: the hero is bhagavān, or "the Beloved Lord," referring to Krishna; GG: the hero is Mādhava, a name for Krishna.

(2) The idyllic scenery-RL: The idyllic scenery is the natural surroundings during the autumn season; the forest at night decorated with flowers which inspires love in the hero; GG: The natural scenery (season not specified in this verse); the forest at night is darkened by clouds with forest's floor darkened by tamāla trees.

(3) The heroine(s) of the story-RL: The group of heroines are the Vraja Gopikās: subtlely indicated by a complex metaphor, the vehicle of which is the imagery of autumnal night blooming jasmine flowers; GG: The heroine is Rādhā, the supreme Vraja Gopikā, the most beloved of all the cowherd maidens.

(4) The "creative power for uniting lovers"-RL: Yogamāyā (literally, "the power of union") the intermediary power that functions to arrange for the divine drama of love between Krishna and the Vraja Gopikās; GG: The words spoken to Rādhā by the unnamed female friend whose intermediary role moves between Rādhā and Krishna throughout the divine drama.
These continuities certainly show how Jayadeva certainly was inspired in his work from the Bhāgavata RL. Juxtaposing them, however, also shows major creative departures: The quoted voice in the first half of the GG verse is the voice of the uniting power of lovers named in the RL verse, Yogamāyā. And it is this voice that urges Rādhā to find Krishna and take him deep into the forest. Then Jayadeva announces most dramatically the intention of his whole work, which sets the GG apart from the RL in several major ways. First, the narrative in the second half of the GG verse most dramatically pictures both Rādhā and Krishna as their joy moves them to retreat deep into the forest, where they are both together conquered by their secret love. While the RL verse declares Krishna's intention to love the cowherd maidens, the GG verse declares his ultimate beloved among them all to be Rādhā, with whom he unites in the secret ways that divine love subsumes them both in their passionate union.

Divine intimacy now takes on new proportions, which is endlessly celebrated in Chaitanya Vaishnavism. Indeed, the personage of Rādhā not only takes on divine status. She is considered a goddess, and moreover, the supreme goddess:

There is an avatārī who manifests just as Krishna does as an avatārī.

She is Rādhā and her divisions become three types of manifestations.

Rādhā is the blissful consort of Govinda, the one who enchants Govinda.

She is utterly everything to Govinda, the crown-jewel of all intimate beloveds. ${ }^{32}$ 
Rādhā's divine status is not only on par with that of Krishna, but above his. Krishna's love of Rādhā places her even above him, to the supreme goddess above all:

Krishna enchants the world, and she is the enchanter of him.

Therefore this goddess (țhākurānī) is the highest of all.

Rādhā is the fullness of all power, and Krishna is the possessor of the full power.

There is no difference between the two, according to the authority of the scriptures. $^{33}$

It is important to note that in the last verse above Krishnadāsa invokes "the authority of the scriptures" when concluding his discussion of Rādhā's apotheosis.

It is reasonable to ask, to what scriptures could Krishnadāsa possibly be referring? After all, no one had articulated the theology of Rādhā the way that Krishnadāsa had done so in the CC, or what his immediate teachers, Rūpa Gosvāmin and Jivva Gosvāmin, had done. The word scriptures implies sacred writings that are well established and accepted by a community of faith. Even Jayadeva's Gitagovinda does not theologically fully explicate Rādhā's divine position.

My theory is that Krishnadāsa's mention of scriptures in the above verse is either obliquely referring to his own work and that of his contemporaries as being authoritative on the subject of Rādhā's divinity and ultimate divine status. Or he is intentionally or unintentionally conflating his contemplation on the divine couple with scriptural sources, expressing that his contemplation on Rādhā and Krishna has the revelational status and authority of scripture. The Bhakti Sūtra speaks of the authoritative power of holy persons in the following words: "As holy persons, they make places holy; as performers of ritual acts, they make all acts auspicious; as true teachers of sacred writings, they make sacred writings truly meaningful." ${ }^{34}$ Thus the authority of scripture originates in special persons or the saintly bhakta, and the bhakta's meditation, in effect, becomes an instrument of revelation that is on par with scriptural authority.

Krishnadāsa's prescriptions for meditation the bhakta's participation and ultimate absorption in the actual divine acts of Krishna, thus imputing an authority easily on par with that of scripture:

Therefore one should reflect the emotions of the Gopis

In thinking day and night about the loving activities of Rādhā and Krishna.

Performing meditation in a perfect body, one can then serve in that place

With the emotions of a sakhi, maidservant, and one attains the feet of Rādhā and Krishna. $^{35}$

“What should be a person's meditation among all objects of meditation?"

"Meditation on the lotus feet of Rādhā and Krishnathis is the chief object of meditation."

"Where should a person make residence, abandoning all other places?"

"The land of Vraja, known as Vṛndāvana, where the Rāsa Lìlā takes place." ${ }^{36}$ 
The uninterrupted, constant reflection on and emotional relating to the loving encounters of Rādhā and Krishna from the position of the Vraja Gopikā-this depth absorption and meditation may itself constitute the sort of scriptural authority of which Krishnadāsa was claiming. Indeed, Chaitanya constantly enacted and exemplified the intense sentiments of a Vraja Gopikā in prayers related by Krishnadāsa in Chaitanya's biography:

O friend, please hear what I have decided.

If he gives me his love, or

if he kills me with unhappiness,

Krishna is the supreme

Lord of my life-

and no one else.

I do not mind my own suffering.

I desire only his happiness.

His happiness-that is my goal.

If he becomes greatly pleased

by suffering given to me,

that suffering-

for me is the greatest happiness. ${ }^{37}$

It is interesting to note here in Chaitanya's words how suffering itself becomes an intimate part of the intensive love of the bhakta, and a positive element in divine intimacy in bhakti. ${ }^{38}$

For Krishnadāsa and the tradition out of which he comes, the person of Chaitanya and his experience in, his example and teaching of Krishna bhakti, is the ultimate source of authority. And this is the reason that Krishnadāsa writes a biography of Chaitanya himself. Indeed, it was on the authority of Chaitanya's experiences in contemplation that give Krishnadāsa the authority to state that Rādhā's divine status is confirmed by scripture.
Chaitanya's visions of Rādhā and Krishna were even greater than that of any scriptural authority for Krishnadāsa, because it is Chaitanya's life that grants authority to the scriptural sources of the school.

\section{Concluding reflections}

Thus, what is started in the Rāsa Lîlā now becomes completed in Krishnadāsa's theopoetic presentation of Chaitanya's vision and example within the Caitanya Caritämrta, and the Gitagovinda is truly the link between the two. Similarly, perhaps we can also say that what is started in the passion, death and ressurrection in the New Testament becomes completed in the theopoetic vision of John of the Cross, and the Song of Solomon is truly the link between the two. These two traditions could be said to be joined together in dialogue, in a special kind of dialogue in which both John and Krishnadāsa celebrate an intense passion within love that both embraces their core canonical visions, on the one hand, and yet must go even beyond them, on other hand, following a craving to go into the deeper dimensions of divine intimacy.

Do they not each share how love is expressed in the dual somewhat paradoxical nature of an embrace? On the one hand, when one embraces another in love, the message sent is one of acceptance, a humility before all that one shares and has with another. On the other hand, such an embrace also sends the message that one wants to know the beloved more deeply, more closely, to enter into the mysterious, more secretive undisclosed dimensions of that love. Both John and Krishnadāsa embrace, as it were, the normative visions of their respective traditions, while they each demonstrate a passion to become 
more intimately and more intensely connected to divinity. This is the interplay between canon and contemplation, between normative canonical visions and key peripheral canonical themes that constitute their individual, intrareligious dialogues.

Can such an embrace also be found between these two traditions? In a dialogue of the kind about which we have spoken earlier in this essay as the third axis of revelation in dialogue? Here we find that dialogue also reflects the two aforementioned dynamics of an embrace as dialectically drawing both partners closer: the one partner who listens, hears with reception, with humility, with a total openness and trust; the other partner, who speaks, offers a gift of words conveying feelings and thoughts out of a certain faith that such a contribution will create a greater closeness, a greater bond of connection, a deeper level of understanding. Then the participation in dialogue shifts: the partner who listens now responds and reciprocates the other partner's contribution to the dialogue. The ever-increasing shifting receiving-andsharing roles of partners in dialogue build a greater sense of community, lifting both partners into an elevated state of the heart. My attempt here in this essay was only to initiate such a dialogue between Carmelite and Chaitanya traditions so that they might reveal shared theological moments within divine intimacy, that they might reveal that much more about divine reality.

There is a point at which theistic traditions of mystical love can no longer be satisfied by or limited to their most important scriptures. They must reach beyond their visions for even greater, but perhaps hidden, revelations of the more intimate dimensions of the divine. At a certain level, such mystics always accept and embrace normative scriptural visions, and yet, at the same time, they reject them as utterly final and desire even greater and deeper revelations of divine intimacy that invariably burst beyond the boundaries of canonical sources by finding their way into poetic and artistic expression. Only these continuously revealed expressions of divine intimacy will satisfy their innermost contemplations that take place within the heart.

What emerges from this deepest interiority of contemplation is a new, transformed, and elevated vision of certain interconnected key scriptural themes that have already been known to practitioners at a certain level but now lifts them up into a new way of seeing scripture. For example, the Carmelite monk or nun can never read the Song of Solomon as it if were mere allegory for the bride and bridegroom, or the soul and Christ. Even if we understand that they may read the work as metaphor, we must understand that it would be a special instance of poetic metaphor: the metaphorical vehicle of the lover-beloved dynamics of lovers of this world does not become swallowed up by the metaphorical tenor as in allegory. Rather, the vehicle becomes so infused with the identity of the tenor that they become inseparable and one and the same.

In other words, the lover in the SS is the bride, she is the soul seeking Christ, she cannot be anything else. As allegory eventually eliminates the value and prominence of the vehicle, causing it to disappear once the reader has arrived at the tenor of the text, so here we have the reverse: the poetic tenor infuses, incarnates, imbues fully and completely the vehicle such that the ostensive imagery of the 
text takes on an iconic power. Perhaps this reversal of allegory could be called "iconegory." Such a reader can never return to the text and perceive its poetic vehicle of the lover and the beloved as worldly lovers. In the same way, the bhakta cannot gaze at the rāsa mandala without seeing, without knowing, without feeling the very glowing presence of Rādhā by Krishna's side at the very center of the great circle dance. Thus the interiority of contemplation permanently and irrevocably establishes new and informative connections intratextually, from which new revelations of divine intimacy emerge in and for the community of faith.

\section{Notes}

${ }^{1}$ There are also indications that such a topic that involves an understanding of God as the supreme lover is becoming increasingly more popular among religious persons in general. Over ten years ago, social researchers observed surprising results in a study that was examining the variety of images persons chose for describing God [see "Images of God among Americans" by Wade Clark Roof and Jennifer L. Roof. Journal for the Scientific Study of Religion, Vol. 23, No. 2, June 1984. http://dx.doi.org/10.2307/1386110]. This study caught the attention of the editors of Psychology Today magazine (June 1985) and USA Today newspaper (May 30, 1985). Among the twelve images of the deity from which to choose, God as "lover" was chosen by nearly half of the people interviewed, and less than one fifth chose God as "spouse." The traditional image of God as "creator" was chosen by over four fifths of persons interviewed. Of note is that the wide diversity of images was found in the religious groups and far less in non-religious groups. This point perhaps indicates that religious conceptions of God are capable of providing multivalent images of the deity perhaps more than that of which we are aware.

2 "Divine intimacy" refers to those portraits of divinity as a divine lover and beloved, for whom souls or divine personages experience a passionate love or the more tender and caring feelings of a parent for a child or the experience of such sweet closeness of a friend with a very close confidant and dear friend. The word intimacy implies a relationship in which the lovers experience an ardent desire for greater and greater closeness to one another in contrast to those relationships that celebrate the greatness, power and majesty of God. Both are theistic, no doubt. But the former represents the "inmost" (from the Latin, intimus) dimensions of the godhead.

${ }^{3}$ Here I refer to the monumental work on philosophical hermeneutics by Hans-Georg Gadamer, entitled, Truth and Method (New York: The Seabury Press, 1975. http://dx.doi.org/2027/uc1.b4244761;

originally published as Wahrheit und Methode [Tübingen: J.C.B. Mohr, 1960. http://dx.doi.org/2027/mdp.39015031608477]), in which he emphasizes the life of a text apart from its author and even to a great extent the text's original historical context.

4 "Comparative Religion: Whither-and Why?" in The History of Religions: Essays in Methodology, edited by Mircea Eliade and Joseph M. Kitagawa (Chicago: University of Chicago Press, 1959), 55. ${ }^{5}$ One of the most celebrative presentations of this Vedic adage can be observed at Satchidananda Ashrama, Yogaville, founded by Swami Satchidananda in Buckingham, Virginia, where he built the Light of Truth Universal Service (LOTUS) temple that celebrates all 
religions. This Vedic passage is prominently displayed there and appears in the literature of the sect.

${ }^{6}$ Rig Veda 1.164.46: ekam sad viprā bahudhā vadanti. Translation mine. Clearly differences between the popular renditions of this passage and the direct translation that I provide here are obvious. For example, no words such as "names" or "paths" exist in the original Sanskrit of this passage. But the intention, I believe, is to express what the passage says most literally. Thus from the earliest sacred writings of India one finds this wise vision that has certainly been a powerful influence on traditions typically grouped under the umbrella term, Hinduism, which certainly includes the Caitanya school of Vaishnavism on which we are focusing here.

${ }^{7}$ In an essay I have written, entitled, "Vaishnava Bhakti Theology and Interfaith Dialogue" (Journal of Vaishnava Studies, Vol. 21, No. 2 / Spring, 2012), I attempt to show the relationship between Vaishnava bhakti theology and dialogue, and how dialogue is greatly valued by the Caitanya school of Vaishnava bhakti. Moreover, I demonstrate not only how dialogue is an essential practice of bhakti, but also how dialogue represents the intrinsic character of bhakti itself. My claim ultimate is that dialogue ultimately has the potential of furthering and deepening a revelation of religious truth.

${ }^{8}$ Opening line of Confessions 10.6. Translated by R.S. Pine-Coffin. Penguin Books, 1970.

${ }^{9}$ The Song of Songs: A New Translation with an Introduction and Commentary, by Ariel Bloch and Chana Bloch (Berkeley: University of California Press, 1995).
${ }^{10}$ Dance of Divine Love: The Rāsa Lìlā of Krishna from the Bhāgavata Purāna: India's Classic Sacred Love Story Introduced, Translated, and Illuminated, by Graham M. Schweig, with a Foreword by Norvin Hein (Princeton: Princeton University Press, 2005). Please note that my numeric references to the verses in the Rāsa Lìlā are those I present in my book, in which I treat the five chapters of the Bhāgavata, tenth book, chapters 29 through 33 (10.29-10-33), as an autonomous drama in five acts, 1 through 5 . These five acts correspond to the Bhāgavata's tenth book, chapters 29 through 33, respectively. The actual number identification for individual verses remain identical.

${ }^{11}$ Note that my use of the terms lover and beloved, both with an initial upper case letter, refer to heroine and hero, respectively. Because the feminine voice is dominant in both the SS and the RL, it deserved an identity in the nominative case. And since the object of the Lover is the masculine hero, I felt it deserved an identity in the participial objective. Thus I use the term beloved to identify hero.

${ }^{12}$ While it is difficult to say exactly what part of scripture especially inspired John to identify the female lover and the male lover in the SS as bride and bridegroom, respectively, there are indeed several places in the New Testament where one can find the word bridegroom engaged, the greater number of which are found in the Gospel of Matthew: Matthew 9:15, 25:1, 5, 6, and 10; Mark 2:19 and 20; Luke 5:34 and 35; and John 2:9; 3:29. The instances in the New Testament in which the word bride is engaged are the following: John 3:29; Revelation 18:23; 19:7; 21:2 and 9; and 22:17. Interestingly, John throughout his complete works only refers to the passage in Matthew 
25.1-13 in his work, The Ascent to Mount Carmel, which contains four instances in which the word bridegroom appears. However, John appears not to derive much inspiration for identifying Christ as the Bridegroom when referencing this passage here in his work.

${ }^{13}$ I have argued that the word erotic in English can mean more than merely the sexual by expanding and deepening its meaning by examining the word's Sanskrit counterpart śrngāra. See the section, "Reconsidering the Meaning of the Erotic" in my article entitled, "The Dance between Tantra and Moksha: On the 'Erotic' Dimension of the Gitagovinda and Krishna Bhakti Theology" (Journal of Vaishnava Studies, Vol. 23, No. 1/Fall, 2013).

${ }^{14}$ The Collected Works of Saint John of the Cross, translated by Kieran Kavanaugh and Otilio Rodriguez (Washington, DC: ICS Publications, 1991. http://dx.doi.org/2027/inu.30000037325 234), 94. All passages quoted in this essay are from this source.

${ }^{15}$ The Collected Works, 94.

${ }^{16}$ John quotes the following passages from the Song of Solomon that express something of the suffering in love: 3:2, 4; 4:9; and 5:6-8.

${ }^{17}$ Stanza 7, The Spiritual Canticle.

${ }^{18}$ Stanza 9, The Spiritual Canticle.

${ }^{19}$ Stanza 35, The Spiritual Canticle.

${ }^{20}$ From John's commentary to Stanza 9 of his work The Spiritual Canticle, 505.

${ }^{21}$ Very little has ever been written about John's crucifixion drawing, which I have found to be a profoundly expressive piece. I have presented a detailed aesthetic and theological analysis of the drawing. See my chapter entitled, "Imagery of Divine Love: The Crucifix Drawing of St. John of the Cross" in St. John of the Cross, Carmelite Studies VI (Washington, DC: Institute of
Carmelite Studies Press, 1992), 162-166. Later I developed my analysis of John's drawing in an article that also engages the Vaishnava tradition comparatively, entitled, "The Crucifixion and the Rāsa Maṇdala: A Comparative Sketch of Two Great Symbols of Divine Love" in Journal of Vaishnava Studies, Vo 21, No. 2 / Spring, 171-185.

${ }^{22}$ St. John of the Cross, Romance 7, "The Incarnation," verses 9-11, The Collected Works of St. John of the Cross, trans. Kieran Kavanaugh and Otilio Rodriquez with an introduction by Kieran Kavanaugh (Washington, DC: Institute of Carmelite Studies Publications, 1964), 67.

${ }^{23}$ See my Dance of Divine Love: The Rāsa Lìlā of Krishna from the Bhāgavata Purāna, India's Classic Sacred Love Story Introduced, Translated and Illuminated (Princeton: Princeton University Press, 2005), 11-19.

${ }^{24}$ GG Act 2, Verse 2. Translation mine.

${ }^{25}$ Śrī Śrī Caitanya Caritāmrta, by Krishnadāsa Kavirāj Gosvāmin, with the Amṛta Pravāha Bhāṣya by Bhaktivinoda Thakura (Calcutta: Gaudiya Mission, 1957), CC 2.8.102, 103, 105, 106, and 107. All translations of verses from the CC are mine.

${ }^{26}$ CC 2.8.109.

${ }^{27} \mathrm{CC} 2.8 .113$.

${ }^{28} \mathrm{CC} 2.8 .114$.

${ }^{29} \mathrm{CC} 3.14 .19$.

${ }^{30}$ First verse of the Rāsa Lîlā from the Bhāgavata Purāṇa (BhP 10.29.1) taken from my Dance of Divine Love, 25 (as Act 1, Scene 1, Verse 1), with one exception: in the translation I provide here in this essay, I use the word "creative" rather than "illusive" found in the original. The transliterated verse is as follows: 


\section{bhagavān api tā rātrih \\ śāradotphulla-malikāḥ \\ vikssya rantum manaś-cakre \\ yoga-māyām upāśritah}

${ }^{31}$ First verse of the Gitagovinda by Jayadeva Goswami. Translation is mine. My intention here is to present a carefully crafted translation. As with much of my translation work, I attempt to bring the unfolding sequence and rhythm of ideas into the translation as a reader of the original Sanskrit verse experiences it. The transliterated verse is as follows:

$$
\begin{aligned}
& \text { meghair meduram ambaram vana- } \\
& \text { bhuvah śyāmās tamāla-drumair } \\
& \text { naktam bhïrur ayam tvam eva } \\
& \text { tad imaṁ rādhe grham prāpaya } \\
& \text { ittham nanda-nideśataś calitayoh } \\
& \text { praty-adhva-kusja-drumam } \\
& \text { rādhā-mādhavayor jayanti } \\
& \text { yamunā-kūle rahah-kelayah }
\end{aligned}
$$

${ }^{32} \mathrm{CC} 1.4 .76$ and 82.

${ }^{33}$ CC 1.4.95 and 96.

${ }^{34}$ The Bhakti Sütra: Self-Illuminating Translations of Närada's Concise Teachings on the Nature of Divine Love, by Graham M. Schweig (New York: Columbia University Press, forthcoming), Sūtra text 69 .

${ }^{35}$ CC 2.8.228 and 229 .

${ }^{36} \mathrm{CC} 2.8 .253$ and 254.

${ }^{37} \mathrm{CC} 3.20 .49$ and 52.

${ }^{38}$ Here, one cannot help but reminisce on John's much more extensive treatment of the role of suffering in love. 